\title{
COMIDA, DIVERSÃO E LIBERDADE. OS TANGUÁS DE CAMPINAS NO FINAL DA ESCRAVIDÃO.
}

\section{Valter Martins}

Universidade Estadual do Centro-Oeste, Campus de Irati/PR

A partir de meados do século XIX a cidade de Campinas, então província de São Paulo, começava a colher de maneira mais intensa os lucros do café cujas primeiras fazendas se iniciaram quando a cana de açúcar ainda dominava sua paisagem e economia. Naquele momento de expansão da fronteira agrícola para exportação, no qual o verde das matas cedia lugar ao verde escuro dos cafezais, escravos eram trazidos de outras áreas do país, ao mesmo tempo em que as primeiras experiências com a mão de obra livre dos imigrantes eram ensaiadas. (DAVATZ, 1980) ${ }^{1}$ A prosperidade econômica da região atraiu muita gente em busca de uma vida melhor. O aumento de sua população rural e urbana, tanto da que chegava de maneira espontânea quanto da que era trazida para o trabalho agrícola, quer por traficantes quer através da política imigratória governamental, fez com que muitas transformações ocorressem na cidade nas décadas que se seguiram à Lei Euzébio de Queiroz.

A construção de um teatro para a diversão de sua elite e de um mercado para garantir o abastecimento urbano com gêneros alimentícios de maneira regular e acessível aos mais pobres na década de 1850, incluiu Campinas entre as cidades brasileiras que mais cedo passaram por uma série de intervenções urbanas que afetaram a vida de seus habitantes. (LAPA, 1996; MARTINS, 2001)

Uma das constantes preocupações das Câmaras Municipais desde os tempos coloniais era prover a população das vilas e cidades com gêneros de primeira necessidade através da organização e fiscalização de seu comércio, previsto nos artigos dos Códigos de Posturas Municipais. Seu cumprimento, ou não, era verificado pelo almotacé ou fiscal, funcionário público com poder de

\footnotetext{
1 José Wells Thompson, morador de Campinas, comprava escravos nas "províncias do norte" sob encomenda, para atender aos seus fregueses mais exigentes. Cf: Gazeta de Campinas, $16 / 11 / 1879$, n. ${ }^{\circ} 1775$, p.3.
} 
multar, apreender mercadorias e até mesmo enviar à cadeia quem violasse as normas prescritas.

Diante das necessidades de ordenar e melhorar o abastecimento urbano com alimentos frescos a Câmara Municipal de Campinas construiu um segundo mercado, o Mercado de Hortaliças², inaugurado em 1872 no estratégico Largo da Cadeia. Sua localização central facilitava a vida de comerciantes e consumidores e, em princípio, facilitaria também o controle e a vigilância daquele espaço e seus freqüentadores por parte dos policiais.

No entanto, a vizinhança do Mercado de Hortaliças parecia concentrar problemas. Por ali circulavam muitos escravos domésticos que faziam compras para as refeições de seus senhores ou que vinham das fazendas com algum trabalho a fazer. Entre uma e outra tarefa na cidade ou em momentos de descanso, os escravos paravam em algum de seus pontos de encontro, vários deles vizinhos ao Mercadinho. Eram verdadeiros territórios negros sob a forma de botequins, cortiços ou quitandas, conhecidas na Campinas daquele tempo como tanguás. Em tais lugares seus freqüentadores, especialmente os escravos, ficavam mais à vontade, como se fossem livres. Assunto por certo não faltava, sobretudo se havia tempo e dinheiro para um copo de "parati": os rendimentos do "ganho"; a quantas andava o pecúlio; um quarto de cortiço bom, barato e bem localizado; o senhor velho, doente e cheio de pecados que fez testamento; os castigos do feitor na fazenda e o desejo de vingança; a novidade mais importante do mundo: uma linda "escravinha" chegada há pouco do norte com seu delicioso sotaque.

Durante aqueles breves intervalos de liberdade, as vozes tantas vezes contidas, ecoavam estridentes pelo ar, em meio ao ruído de copos, louças, balanças e, quem sabe, cantigas alegres ou tristes da velha África. Apesar da condição escrava ser comum a muitos dos que se reuniam naqueles lugares, nem sempre reinava um clima de paz e fraternidade. Vez ou outra, seu movimento incomodava a vizinhança e acabava execrado nas páginas dos jornais.

Há em frente ao mercadinho uma baiúca pertencente a um indivíduo de nome Manoel Quirino, onde se reúnem

2 O Mercado de Hortaliças ficou conhecido como "Mercadinho" para distingui-lo do primeiro mercado da cidade, chamado de Mercado Grande após a inauguração do Mercadinho.

URBANA, ano 2, n² 2, 2007, Dossiê: Cidade, Imagem, História e Interdisciplinaridade. 
ordinariamente escravos e ali fazem algazarra atroadora. Na tal baiúca, joga-se e armam-se rixas a cada passo. O Sr. delegado já fez recomendação especial à guarda da cadeia para impedir que continuem as brigas e jogatina, porém, até agora a referida guarda nada tem feito e as coisas estão no mesmo estado" ou "será possível a polícia não ver o deboche que se pratica entre negros e negras cativos em um quarto na rua da América, em frente ao mercadinho? Pois vão para ali e passam quase todo o dia pintando o sete, faltando com as obrigações aos seus senhores (...) de certo a polícia anda dormindo ou faz parte do pagode. ${ }^{3}$

A escravidão era cruel, mas os escravos encontravam maneiras criativas de fruírem as boas coisas da vida dentro de suas possibilidades, pelo menos por alguns momentos. O prazer e a alegria em suas variadas formas eram um meio de subversão da ordem escravista. Isso era motivo mais que suficiente para que tais locais de reunião fossem suspeitos aos olhos das autoridades.

O Largo da Cadeia, no qual se localizava o Mercadinho de Hortaliças (além da própria cadeia que abrigava a Câmara Municipal e do Tribunal do Júri), tornou-se um dos locais mais freqüentados e animados da cidade. Nas sujas ruas ao seu redor, velhas casas de taipa transformadas em cortiços abrigavam gente pobre da rica Campinas. Negros, mulatos e brancos, brasileiros ou imigrantes, compartilhavam a insalubridade, a falta de conforto e as dificuldades da pobreza e da escravidão.

O Mercadinho funcionava havia mais de dez anos quando surgiu um movimento para substituí-lo por um novo Mercado de Hortaliças, maior, mais bonito, higiênico e em outro lugar. Entre os argumentos de um abaixo-assinado enviado à Câmara, sugerindo a mudança do Mercadinho do Largo da Cadeia para o Largo da Liberdade, um deles buscava prevenir a dispersão do comércio de hortaliças e quitandas pela cidade. Apontada como prejudicial à higiene pública, a dispersão daquele comércio dificultaria a fiscalização da salubridade dos gêneros alimentícios. ${ }^{4}$

\footnotetext{
${ }^{3}$ Diário de Campinas, 18/05/1883, n. ${ }^{0}$ 2241, p.2; Gazeta de Campinas, 08/07/1883, n. ${ }^{\circ}$ 2837, p.2. A "baiúca" existia desde pelo menos 1882 e, segundo o Diário, para ali acorriam negras e mulatas logo que ficavam forras "para pilhar o bom cobrinho". O Diário insinua que ali havia um provável cáften, por alcunha "Papai". Para muitas mulheres, a liberdade acabou tornando-se verdadeiro castigo. A dificuldade de encontrar trabalho com remuneração suficiente para seu sustento e de sua família, não poucas vezes as obrigavam a buscar na prostituição uma alternativa de sobrevivência. Cf: Diário de Campinas, 14/06/1882, n. 1973, p.2. Sobre a prostituição feminina movida pela situação de extrema pobreza veja: (FIGUEIREDO, 1993; DIAS, 1984)

4 Arquivo da Câmara Municipal de Campinas (Arq.CMC de agora em diante), cx. C1/4, pasta.1885/II, 10/08/1885.
}

URBANA, ano 2, n² 2, 2007, Dossiê: Cidade, Imagem, História e Interdisciplinaridade. 
Enquanto se discutia o futuro do Mercado de Hortaliças os verdureiros e quitandeiras com dificuldades para vender seus produtos naquele local aos poucos começaram a se estabelecer em pequenos negócios nas vizinhanças.

A Câmara decidiu pela demolição, notícia que provocou furor no Mercadinho. Vicente Russo, José Pierri, Emídio Perrella, Fiel de Belisário, João Rodrigues, Miguel Marotta, Joaquim Congo, Benedito Fiúza, Bento Bueno, Vicente Tommaso e Manoel Quirino, negociantes que já haviam pago suas licenças até o final do ano de 1885, oficiaram à Câmara pedindo que "não seja demolido o referido mercadinho antes que o novo se ache pronto, visto o vexame que lhes causará este fato se, tal como consta, acontecer". Através da Comissão de Obras Públicas, a Câmara indeferiu o pedido dos comerciantes alegando que os materiais da demolição do Mercadinho seriam usados na construção do novo, determinando que fossem reembolsados no que thes coubesse ou que usufruíssem de sua licença transferindo-se para o Mercado Grande. ${ }^{5}$

Desalojados, vários comerciantes e quitandeiros do velho Mercadinho de Hortaliças armaram suas tendas no Mercado Grande, esperando ficar ali até que o novo Mercadinho fosse inaugurado. Bastaram poucos dias para que o novo endereço se revelasse bastante complicado para os negócios. No Mercadinho os comerciantes desfrutavam de grande liberdade pois nele não havia um inspetor que vigiasse seus movimentos o tempo todo. No Mercado Grande as coisas eram diferentes. A presença cotidiana do inspetor provocou atritos com alguns dos recém chegados: uma vendedora de lingüiça frita, um "preto mina" de tabuleiro e um quitandeiro. Talvez porque o inspetor tenha sido afoito ao tentar impor sua autoridade aos novos inquilinos ou porque tivesse um gênio um tanto difícil, os quitandeiros do antigo Mercadinho perguntavam se, afinal, podiam ou não trabalhar ali. 6

A estadia dos comerciantes do Mercadinho no Mercado Grande foi tão breve quanto atribulada. Depois de se queixarem aos fiscais sobre os contratempos sofridos, pediram permissão para trabalharem ao ar livre na praça onde antes existia o Mercadinho, o que Ihes foi concedido. ${ }^{7}$

\footnotetext{
5 Atas da Câmara Municipal de Campinas (ACMC de agora em diante), 10/09/1885; ACMC, 21/09/1885; ACMC, 03/12/1886; Arq.CMC, Cx. C1/4, pasta 1885/II, sem data.

${ }^{6}$ Correio de Campinas, 27/08/1885, n.o 193, p.2; Correio de Campinas, 25/09/1885, n. 0 217, p. 2; Correio de Campinas, 02/10/1885, n. ${ }^{\circ} 223$, p.1.

7 Correio de Campinas, 07/10/1885, n. 0227 , p.1.
} 
A demolição do Mercadinho provocou exatamente o que se desejava evitar com a construção de um mercado maior: a dispersão dos verdureiros e quitandeiros. Ocorrida 14 meses antes da inauguração do novo Mercadinho de Hortaliças, deixou muitos comerciantes e quitandeiros em dificuldades. Aqueles que optaram pelo Mercado Grande se arrependeram logo e os demais acabaram por montar pequenos negócios de quitandas, que ficaram conhecidos como "tanguás".

Enquanto se construía o novo Mercadinho aquelas pessoas tinham que ganhar sua vida e encontraram nos tanguás a solução para continuarem trabalhando no ramo. Essa proliferação dos tanguás pela cidade acarretaria problemas para o novo Mercadinho, tanto quanto, à moral e salubridade públicas.

A inauguração do novo Mercado de Hortaliças ocorreu ao meio dia de 24 de dezembro de 1886 e mobilizou a Câmara Municipal, representantes da imprensa, funcionários municipais e o "Zé Anônimo", que enchia o local todo decorado com bandeiras. Discursos, banda de música, foguetes, cerveja grátis para todos: "tudo muito bom; não faltou nada... a não ser os quitandeiros que se tinham acocorado nos seus quartinhos, que o Dr. Ricardo designou com o nome de tanguás." Assim, em meio aos vivas e elogios ao novo mercado, uma observação do Correio de Campinas era reveladora: não fosse pelas "pobres uvas e uns tristes maxixes", levados pelo único comerciante que arriscou comparecer, a inauguração do Mercado de Hortaliças teria acontecido sem nenhuma hortaliça. As mesas de "mármore do pantojo" ficaram nuas e frias. ${ }^{8}$

Os dias passaram e o novo Mercado de Hortaliças estava às moscas. O fiscal da freguesia de Santa Cruz onde o mesmo se localizava, Luís Antonio Barbosa, oficiou à Câmara recém empossada comunicando que até 10 de janeiro de 1887 havia alugado apenas uma banca, no dia da inauguração. Aproveitando a ocasião, sugeriu que o preço do aluguel das bancas fosse reduzido. $O$ Mercadinho, orgulho da Câmara que o havia construído e inaugurado, parecia estar destinado ao fracasso caso algo não fosse feito. Caberia aos novos vereadores resolver o problema, além de arcar com a dívida herdada relativa à construção. Iniciou-se uma campanha para atrair comerciantes e quitandeiros

8 Correio de Campinas, 04/01/1887, n. ${ }^{0}$ 599, p.1. Veja também: Diário de Campinas, 25/12/1886, n.o 3320, p.2.

URBANA, ano 2, n² 2, 2007, Dossiê: Cidade, Imagem, História e Interdisciplinaridade. 
para o novo Mercadinho. A sugestão do fiscal foi acatada e o aluguel das bancas foi reduzido de $120 \$ 000$ réis para $60 \$ 000$ réis anuais. Sem resultados, seguiu-se nova redução, dessa vez para $40 \$ 000$ réis anuais. Ainda assim, o lugar continuou pouco freqüentado por comerciantes e quitandeiros. Diante das dificuldades para dar pleno uso ao seu mais novo melhoramento urbano, a Câmara convidou os comerciantes para se instalarem no novo mercadinho gratuitamente pelo período de 1 ano, desde que respeitassem o regulamento. ${ }^{9}$

Mas, até que a Câmara chegasse a essa medida um tanto drástica em janeiro de 1888, é preciso retornar aos tanguás. Espalhados pela cidade, aqueles pequenos estabelecimentos fizeram grande sucesso entre os consumidores, especialmente os mais pobres. ${ }^{10}$ Os tanguás estavam onde o povo estava: nos bairros, nos cortiços, no centro da cidade. Com o Mercadinho, a Câmara visava centralizar em um único lugar, restrito e vigiado, um tipo de comércio que era visto com muitas reservas porque envolvia escravos, libertos e imigrantes, homens e mulheres livres pobres que circulavam pelas ruas e facilitavam a vida de muitas cozinheiras e donas de casa.

Quando o novo Mercadinho de Hortaliças foi inaugurado os proprietários dos tanguás, muitos deles antigos quitandeiros no Mercadinho demolido, estavam estabelecidos e tinham formado sua própria freguesia. Inicialmente o aluguel de uma banca no mercadinho era muito alto, nada atraente aos comerciantes de hortaliças, frutas, quitandas, aves e carne. Havia ainda o problema da autonomia. Nos tanguás os quitandeiros faziam seu próprio regulamento enquanto no Mercadinho tinham que sujeitar-se ao regulamento da Câmara. Levando em conta essas e outras possíveis razões, os donos de tanguás avaliavam não ser vantajoso alugar banca no mercadinho: novo, bonito e higiênico que fosse. Essa atitude repercutiu de maneira decisiva no Mercadinho. Bastava uma visita ao local para verificar que estava praticamente sem comerciantes, sem mercadorias e sem consumidores. ${ }^{11}$

O vereador Ricardo Gumbleton Daunt sugeriu em dezembro de 1886 que a Câmara enviasse à Assembléia Provincial um artigo de postura alterando a tabela de impostos então em vigor, propondo que o imposto sobre negócios de

\footnotetext{
9 Arq.CMC, cx. C3/4, pasta 1887/I, 10/10/1887; ACMC, 10/01/1887; ACMC, 20/01/1887; ACMC, 21/02/1887; Gazeta de Campinas, 23/03/1887, n.o 3944, p.2; ACMC, 23/01/1888.

${ }^{10}$ Diário de Campinas, 22/01/1887, n. ${ }^{0} 3341$. p. 1

${ }^{11}$ Veja: Diário de Campinas, 09/01/1887, n. ${ }^{\circ} 3330$, p. 1.
} 
quitandas, conhecidos como tanguás, fosse elevado a $100 \$ 000$ réis anuais. Procurando um meio de tornar o novo Mercado de Hortaliças útil ao fim a que se destinava, a Câmara que o construiu e inaugurou teve na aprovação do novo e indecoroso imposto sobre tanguás um de seus últimos atos antes do fim de seu mandato. A medida visava desestimular aquele tipo de estabelecimento e, ao mesmo tempo, forçar que aquele comércio procurasse o seu "devido lugar", o Mercadinho de Hortaliças. ${ }^{12}$

O novo Mercadinho era um verdadeiro fiasco comercial. Em janeiro de 1887 o Diário de Campinas ponderava que havia sido um grande erro da Câmara anterior permitir a demolição do "imundo pardieiro" (o antigo Mercadinho), antes de ter construído o novo edifício. O proibitivo imposto de $100 \$ 000$ réis para funcionamento de tanguás foi oficializado através da lei no. 73. A explícita finalidade do imposto ganhou apoio nas páginas dos jornais. Segundo o Correio de Campinas, "vamos ver agora se se consegue que os quartinhos [tanguás] se fechem e se encha o mercado de verduras". ${ }^{13}$

Muitos, entretanto, eram contra. Para o Diário de Campinas, o imposto era mais que vexatório, era "absurdo". ${ }^{14}$ O valor total do imposto para os tanguás deveria ser pago à vista no início de cada ano enquanto o aluguel de uma banca no novo mercado era menor e dividido em mensalidades. Com grande abuso de sua autoridade a Câmara buscava impor o novo mercadinho aos pobres comerciantes e ao público.

Se o Diário era contra o imposto que "esmagaria inteiramente uma classe tão modesta quanto ativa e prestante", o Correio não apenas era a favor como o considerava baixo. Especulando sobre as causas da "aversão" dos quitandeiros em alugar bancas no Mercadinho (por $5 \$ 000$ réis mensais), e onde encontrariam ainda melhores condições higiênicas e de trabalho, o Correio considerava que uma delas era a facilidade que tinham para estabelecerem seus tanguás pela cidade.

Outro detalhe ajudava "explicar" aquela resistência. Os tanguás eram vistos por parte da sociedade e autoridades como

\footnotetext{
12 ACMC, 27/12/1886.

13 Diário de Campinas, 09/01/1887, n. ${ }^{\circ} 3330$, p.1; Correio de Campinas, 29/04/1887, n. ${ }^{\circ}$ 692, p.1; Correio de Campinas, 23/01/1887, n. ${ }^{\circ} 615$, p. 1.

${ }^{14}$ Diário de Campinas, $12 / 01 / 1887$, n.o 3332 , p.1.
} 
valhacouto de vagabundos e mulheres vadias, onde 0 vício encontra todas as facilidades para 0 seu desenvolvimento. As mesas do mercadinho não podem certamente dar aos alugadores os rendimentos das quitandas estabelecidas nos becos e lugares escusos. ${ }^{15}$

O fato de um fiscal ter informado que alguns quitandeiros preferiam pagar o alto imposto a mudarem-se para o Mercadinho foi motivo para que o Correio reivindicasse um imposto ainda maior, para que se atingisse dois objetivos com apenas uma medida: "povoar de quitandeiros o novo mercado e fechar os infectos e prejudicialíssimos tanguás". Afinal, eram "baiúcas onde a devassidão campeia desbragada". ${ }^{16}$

Havia certa imprecisão quanto à terminologia utilizada para referir-se àqueles espaços de variados comércios e freqüentadores. Tal imprecisão confundia até mesmo os homens da imprensa: "tanguás... biombos, ou que diabo é!", perguntava um articulista Correio de Campinas em janeiro de 1887. ${ }^{17}$ O fato de vários tanguás funcionarem em cortiços ou vizinhos a eles, possivelmente tenha contribuído para associar aquele comércio aos cortiços e seus moradores, tidos, até prova em contrário, como gente suspeita.

À rua do General Osório n. ${ }^{\circ}$ 66, há um biombo que é um couto de raparigas alegres da última espécie, e o ponto de reunião do rebotalho do sexo masculino. Aparentemente aquilo parece uma quitanda. Mas as quitandas que ali se dão a dinheiro, o diabo as queira ver! Fazem arrepiar os cabelos! ${ }^{18}$

Os tanguás podiam ser associados às pobres moradias das prostitutas, em geral os "biombos", ou também ser apresentados com características de botequim. Um dos mais famosos tanguás/botequins da cidade localizava-se na Rua do Góis, esquina com o Largo Carlos Gomes, próximo ao Mercado Grande. Nele os "forrobodós e a sanfona, repetem-se todos os dias e aquela casa está se tornando o "great atraction" de quanto sujeito mal encarado anda aí por essas ruas. Qualquer dia teremos ali bordoeira grossa. Ao menos se a polícia entrasse no fandango". No domingo em que o Correio publicou essas palavras ácidas

\footnotetext{
${ }^{15}$ Correio de Campinas, 30/01/1887, n. ${ }^{\circ} 620$, p.1 (grifo meu).

${ }^{16}$ Correio de Campinas, 13/02/1887, n. ${ }^{0}$ 631, p. 1.

17 Correio de Campinas, 04/01/1887, n.o 599, p.1. O termo biombo, em princípio, era utilizado para referir-se aos cortiços quando associados à prostituição.

${ }_{18}$ Diário de Campinas, 06/02/1881, n.0 1579, p.3.
} 
sobre o tanguá da Rua do Góis, por coincidência a animação ali foi tamanha que dois indivíduos acabaram se estranhando. Saindo à rua para resolverem suas diferenças, um deles disparou um tiro de pistola sobre o outro, sem maiores conseqüências. ${ }^{19}$

Tanguás, vendas, biombos, botequins e quitandas. Esses termos mal delimitados quanto aos seus papéis e funções, muitas vezes eram utilizados como sinônimos, chamados desdenhosamente também de "baiúcas", indicando estabelecimentos nos quais tradicionalmente se vendiam verduras, frutas e quitandas, mas que podiam oferecer também aguardente e outros gêneros alimentícios, para serem consumidos no local ou não. Sob o pretexto das compras cotidianas, do descanso ou de uma refeição, desenvolviam-se ali momentos de intensa vida social e trocas culturais das classes populares: a conversa, o "mata-bicho", o jogo, a dança e até mesmo o trabalho, no caso dos donos desses estabelecimentos e das prostitutas. 20 Eram lugares de abastecimento e lazer de gente simples e que, por isso mesmo, podiam em seus recônditos ocultar transgressões e conspirações as mais variadas. Pelo menos na opinião de vereadores e policiais.

Nas transformações urbanas das décadas finais do Oitocentos implementadas por higienistas e sanitaristas, os tanguás, os cortiços e outros tipos de habitações da população mais pobre foram considerados verdadeira ameaça. Ao receber notícias sobre a ocorrência do cólera na Ilha Grande, província do Rio de Janeiro, considerava o médico e vereador Ricardo Daunt "que é de notoriedade pública o estado imundo do interior das casas conhecidas por tanguás, e da falta de asseio em que vivem os indivíduos na maior parte das casas aglomeradas, tornando-se por isso um perigo à saúde pública a existência de tais casas...". Para Daunt, os perigosos tanguás deveriam ser fechados ao menos temporariamente, sendo negadas pela Câmara novas licenças para seu funcionamento.

${ }^{19}$ Correio de Campinas, 22/05/1887, n. ${ }^{\circ}$ 711, p.2; Gazeta de Campinas, 24/05/1887, n. ${ }^{\circ}$ 3994, p.2.

$20 \mathrm{O}$ espaço das vendas e quitandas, muitas vezes comandadas por mulheres, era visto como foco de tensões sociais pelas autoridades desde os tempos coloniais. Cf: (FIGUEIREDO, 1993) especialmente o capítulo I. 
Na guerra declarada aos tanguás pela Câmara não bastou a criação de um imposto proibitivo aos seus proprietários. ${ }^{21}$ Todos os meios foram utilizados para atingir aqueles locais de comércio e sociabilidade popular, enfatizando sempre suas características consideradas as mais negativas e reprováveis, atribuídas igualmente a seus freqüentadores, considerados vadios e indecentes.

Os tanguás campineiros tinham várias semelhanças com os zungús cariocas. As múltiplas possibilidades de utilização de seu espaço, notoriamente pelos negros e a indefinição do que vinham a ser exatamente, atormentavam as autoridades municipais e policiais que, a pretexto de combater problemas sanitários, de ordem e moral públicas, tinham aqueles locais sob estreita vigilância.

Os zungús do Rio de Janeiro durante o século XIX tinham forte matiz africano, expresso não apenas pelo nome, mas pelas pessoas que reunia: negros escravos, libertos e livres, e pela comida que neles era servida: o angu. Mas os zungús, originalmente casas de angu, se revelaram também vendas de quitandas, moradias coletivas de curta permanência, casas de culto religioso, esconderijos temporários para escravos em fuga para os quilombos do interior, esconderijos para escravos fugidos que permaneciam na mesma cidade de seus senhores, entre outras serventias, todas dignas de censura do ponto de vista das autoridades. Representando um perigo em si, e pelo que podiam ocultar, os zungús incomodavam muito aos que não eram iniciados em seus muitos mistérios. A tentativa de proscrever tais territórios negros no Rio de Janeiro data de 1833, quando a Câmara Municipal da Corte teve aprovada a postura de nº. 8:

São proibidas as casas conhecidas vulgarmente pelo nome de casas de zungú e batuque. Os donos ou chefes de tais casas serão punidos com penas de 8 dias de prisão e $30 \$ 000$ réis de multa e nas reincidências em 30 dias de prisão e $60 \$ 000$ réis de multa. (SOARES, 1998: 26-27)

\footnotetext{
${ }^{21}$ ACMC, 31/12/1886; Arq.CMC, Livro de correspondências 1886/1892, p. 23v, 24. A Câmara enviou ofício à Assembléia Legislativa Provincial pedindo aprovação da criação do "imposto proibitivo sobre os pequenos negócios de quitandas, conhecidos como tanguás, e que se reputam inconvenientes à saúde pública", somente em 31 de janeiro de 1887, "coincidentemente", depois do Mercado de Hortaliças estar aberto e vazio havia mais de um mês. O teor do artigo único relacionado aos tanguás dizia o seguinte: "O imposto atual sobre casas de negócio de quitandas, conhecidas como tanguás, fica elevado à taxa anual de $100 \$ 000$ réis". Cf: Arq.CMC, Livro de correspondências 1886/1892, p. 25v, 26. Não há notícias sobre a Câmara ter negado licenças para tanguás.
}

URBANA, ano 2, n² 2, 2007, Dossiê: Cidade, Imagem, História e Interdisciplinaridade. 
Em 1876 a Câmara Municipal de Campinas teve aprovada pela Assembléia Legislativa Provincial um novo Código de Posturas. Com seus 385 artigos, aos quais juntavam-se os regulamentos do Mercado Grande, do Mercado de Hortaliças e a nova Tabela de Impostos, ficou conhecido como o "código dos disparates", sendo banido pelo clamor irado do povo.

Até que surgisse um novo código em 1880, muitos artigos do código dos disparates, combinados com artigos de códigos anteriores, eram usados na medida das necessidades, resolvendo aqui, remediando acolá. Entre os artigos do Código de 1876, em seu Título IV - "Sobre vozerias nas ruas, injúrias e obscenidades contra a moral pública", encontrava-se o de no. 93: "São proibidas as casas conhecidas vulgarmente pelo nome de casas de zungús e batuques. Os donos ou chefes de tais casas serão punidos com penas de 8 dias de prisão e $30 \$ 000$ réis de multa, e o dobro nas reincidências". Essa cópia deslavada do antigo Código carioca, ou de algum outro código pouco original, aliás, prática bastante usual nas Câmaras do Brasil naqueles tempos, faz pensar no porquê da inclusão de tal artigo no código campineiro.

O termo zungú apareceu na Gazeta de Campinas em 1886 (pouco antes da inauguração do novo mercadinho!), em uma reclamação enviada por "uma pessoa ciosa da moral pública". Dizia um cidadão que na Rua Lusitana, entre as ruas Conceição e do Góis, havia um "zungú".

Aí praticam-se todos os dias as cenas mais vergonhosas e indignas. Também na Rua Conceição, próximo à Rua Direita, em uma casa de quitanda, reúnem-se todas as noites uma súcia de sujeitos de todas as cores e de todas as idades que estão mesmo a pedir a atenção da polícia. ${ }^{22}$

O zungú aparece aqui como democrático espaço de reuniões das classes populares que para muitos eram, no mínimo, suspeitas, a exemplo das que aconteciam na mencionada casa de quitandas ou tanguá da rua Conceição, no centro da cidade.

Exceto por essa referência no jornal e no Código de Posturas de 1876, a palavra zungú parecia não ser muito usual em Campinas. Entretanto, aparentemente, o artigo 93 do Código de 1876, proibindo zungús, tinha sua razão de ser. A "capital agrícola" de São Paulo absorvia cada vez mais

\footnotetext{
${ }^{22}$ Gazeta de Campinas, $15 / 10 / 1886$, n. ${ }^{\circ} 3818$, p.1.
} 
mão-de-obra para seus insaciáveis cafezais. A concentração de grande população escrava, inclusive de outras regiões e províncias, circulando nas vizinhanças e mesmo na cidade, não era algo a ser ignorado pela polícia de Campinas que possuía um contingente reduzido e seria incapaz de enfrentar uma revolta.

Os pontos de encontro, de troca de experiências e informações de homens e mulheres cativos ou não em Campinas remetiam aos tanguás, tanto quanto os chafarizes e praças. Provavelmente, os tanguás fossem a versão local, ainda que diluída, dos zungús cariocas, mesclando negros e brancos, escravos e livres. ${ }^{23}$ As reuniões em tais lugares poderiam ter conseqüências nefastas na visão da Câmara e da polícia campineiras, uma preocupação que permaneceu além dos limites do Império. Na primeira tabela de impostos dos tempos republicanos em Campinas, de julho de 1890, os negócios de quitandas aparecem denominados também como "frejes" e "casas de comida". As quitandas/frejes evocavam os tanguás, espaços nos quais não ocorria somente o comércio de alimentos. Os zungús, conhecidos ou não por esse termo em Campinas ou, na prática, conhecidos por tanguás, marcaram sua presença na vida da cidade e de seus habitantes naquele tempo de mudanças. ${ }^{24}$

Enquanto os tanguás resistiam às investidas dos que desejavam sua extinção e continuavam sua agitada rotina em diferentes pontos da cidade, o Mercadinho de Hortaliças seguia pouco freqüentado por comerciantes e consumidores.

Para completar aquele quadro de dificuldades os quitandeiros ambulantes e dos tanguás não ficaram nada satisfeitos com o novo regulamento do Mercado de Hortaliças, aprovado pela Câmara em 1886. Por ele teriam que permanecer no novo mercadinho até às 10 horas da manhã para terem seus produtos inspecionados, o que causaria atrasos e prejuízos, uma vez que os consumidores esperavam suas mercadorias logo pela manhã. Afinal, eram tempos de fogão à lenha e a comida para o almoço tinha seu preparo iniciado horas antes de ir à mesa. Para alegria dos quitandeiros ambulantes e de muitas donas de casa, a medida foi alterada em pouco tempo. Por sugestão de seu presidente, Otto

\footnotetext{
${ }^{23}$ Não foi possível decifrar a origem do termo tanguá, especialmente associado à venda de quitandas e outros alimentos, muito menos com botequins ou moradias coletivas. Os dicionários silenciam diante da palavra e quando se manifestam, como o de (FREIRE, 1957) que diz apenas: "Tanguá: pedra com buracos".

${ }^{24}$ Cf: Arq.CMC, Livro de Posturas e Regulamentos 1884/1891, p.167.
} 
Langgaard, a Câmara ajustou o regulamento aos horários e hábitos alimentares da população, permitindo que os gêneros alimentícios vendidos pelos ambulantes pudessem ser fiscalizados a qualquer momento onde quer que fossem encontrados pelos fiscais ou por seus ajudantes, sem que precisassem permanecer um tempo determinado no Mercadinho. ${ }^{25}$

A insatisfação com o novo regulamento havia provocado reações até mesmo em:

\begin{abstract}
gente que se presa, gente que dança no Club Semanal e que não mete os dedos no nariz mas que tem carroça de quitanda, de leite e melado, e que também protesta contra o regulamento porque este tem o desaforo de não se lembrar de atender ao interesse de cada um em particular. ${ }^{26}$
\end{abstract}

O ramo das quitandas podia, em alguns casos e ao cabo de anos de trabalho duro, proporcionar até mesmo uma vida de relativo conforto ou, o mais provável, ser objeto de investimento de aburguesados campineiros.

Além dos tanguás, do aluguel alto das bancas e do regulamento restritivo, outro problema contribuiu para que o Mercado de Hortaliças tivesse uma fase inicial bastante desapontadora: a distância do centro da cidade. Um ano após a Câmara ter convidado os quitandeiros a se estabelecerem gratuitamente no Mercadinho, bastando apenas cumprirem o regulamento, Joaquim José Batista, Daniel Francisco, Manoel Simões Bogalho e mais 17 quitandeiros, oficiaram aos vereadores pedindo autorização para estacionarem no Largo Visconde de Indaiatuba com seus gêneros das seis às oito e meia da manhã "porque o mercado de verduras é distante do centro da cidade". ${ }^{27}$

\footnotetext{
${ }^{25} \mathrm{O}$ parágrafo primeiro do artigo primeiro do regulamento do Mercado de Hortaliças, determinava os gêneros alimentícios que seriam vendidos em suas dependências e sua fiscalização: "Hortaliças e legumes de todo gênero e espécie, palmitos, leite, frutas, doces, café em pó e em líquido, peixe e bem assim todos os outros gêneros comestíveis, chamados de quitanda. Os importadores poderão vendê-los também pelas ruas e praças, ficando porém obrigados a estacionarem nas varandas do respectivo mercado até às 10 horas do dia, para convenientemente pelo fiscal ou administrador da mesma praça serem examinados os gêneros destinados ao consumo público. Os que contrariarem esta disposição serão multados em $5 \$ 000$ réis e o duplo nas reincidências". Os parágrafos $2^{\circ}, 3^{\circ}$, $4^{\circ}$ e $5^{\circ}$ do mesmo artigo primeiro, tratavam de outros produtos que também poderiam ser comercializados no Mercado de Hortaliças: "louças de indústria nacional", aves e "animais esquartejados como sejam: leitões, cabritos, carneiros, etc". Cf: Regulamento do Mercado de Hortaliças de 1886, Arq.CMC, Livro de posturas e regulamentos, 1884/1891, p. 94-98. Veja sobre as mudanças no regulamento: ACMC, 20/01/1887; ACMC, 31/01/1887; Arq. CMC, Livro de correspondências 1886/1892, pp. 28v e 29, 21/02/1887.

${ }^{26}$ Correio de Campinas, 04/01/1887, n. ${ }^{\circ} 599$, p. 1 e 3.

27 ACMC, 23/01/1888; ACMC, 07/01/1889. Um mês depois desse pedido ter chegado à Câmara, irrompeu a grande epidemia de febre amarela que desorganizou a vida da cidade. Ao que tudo
}

URBANA, ano 2, n² 2, 2007, Dossiê: Cidade, Imagem, História e Interdisciplinaridade. 
Esse argumento parecia um tanto contraditório. Quando se discutiu a mudança do Mercado de Hortaliças para o Largo da Liberdade, entre os motivos alegados pelos que eram favoráveis ao novo mercado constava a boa localização (em frente ao Mercado Grande) e o fácil acesso dos consumidores. Tanto era verdade que o antigo mercadinho distava apenas uma quadra do largo Visconde de Indaiatuba, conhecido também como Largo do Rosário. O novo Mercado de Hortaliças estava apenas a duas quadras de seu antecessor demolido. Para os quitandeiros, no entanto, duas quadras a mais pareciam representar um grande empecilho aos seus negócios. Talvez porque para os consumidores que vinham de longe - a pé, a cavalo, de carroça ou de bonde, qualquer quadra a mais fazia muita diferença.

A cidade havia se expandido em direção à estação ferroviária, deslocando grande parte do comércio concentrado nas ruas do Comércio e Direita, para as ruas São José e Bom Jesus usadas para ir ou voltar da estação. O Mercado de Hortaliças e o Mercado Grande estavam no lado oposto àquela expansão, ainda que não estivessem distantes do Largo Visconde de Indaiatuba, o mais central de Campinas.

A edilidade deveria estar desiludida com o fraco desempenho de seu Mercado de Hortaliças e sem mais idéias para tentar mudar o rumo das coisas. Em 1889, o vereador Ricardo Daunt radicalizou propondo a demolição do Mercadinho mas com o cuidado necessário para que o material não fosse danificado para ser reaproveitado. A proposta foi rejeitada porque um edifício novo e que havia custado caro à municipalidade, poderia ter alguma utilidade. Enquanto a Comissão de Saúde Municipal, liderada pelo Dr. Ângelo Simões e Ataliba Florence registrava mais um óbito por febre amarela na cidade, o Dr. Daunt levava nova proposta aos colegas: que a Câmara dividisse o prédio do Mercadinho em 14 compartimentos e os alugasse para depósito e comércio de gêneros inflamáveis e explosivos. Essa nova idéia perdeu-se em meio à terrível

indica, estabeleceu-se no Largo Visconde de Indaiatuba um mercado de hortaliças ao ar livre. 0 funcionamento desse "mercado alternativo" teve breve duração, sendo extinto pela Intendência Municipal através da resolução n. ${ }^{0} 11$, de 20 de maio de 1890 que dizia: "Ficam proibidas as vendas de verduras, aves etc, na praça Visconde de Indaiatuba, devendo ser feitas no mercado respectivo. É proibido aos quitandeiros postarem-se em qualquer lugar para venderem, sob pena de $5 \$ 000$ réis de multa. Este artigo de postura deve vigorar de $1^{0}$ de junho próximo em diante". Veja: Intendência Municipal de Campinas, Resoluções relativas aos anos de 1890 a 1892 , Campinas: Tip. Livro Azul, 1900, p.9. Veja também: ACMC, 20/05/1890. 
epidemia de febre amarela que se abateu sobre Campinas no primeiro semestre de 1889. Passada a tragédia, a cidade enlutada e ainda perplexa retomava suas atividades quando, no início de setembro, o sobrevivente Daunt retornou com mais uma possível solução para o aproveitamento lucrativo do edifício do Mercadinho. Desta vez, sugeriu a transformação do mesmo em quartel da força pública, gerando seu aluguel uma renda satisfatória à Câmara. ${ }^{28}$

Certamente, a conjunção dos fatores discutidos até aqui, contribuíram para fazer com que quase três anos após sua inauguração o novo Mercado de Hortaliças ainda estivesse subutilizado, sem servir ao público e sem gerar rendas aos cofres municipais. Entretanto, a Câmara ainda não sabia o que fazer com o prédio do Mercado de Hortaliças quando aconteceu o que parecia mais improvável. Chegou ao Paço Municipal uma representação assinada por João Ferreira, João Alves \& Cia. mais 29 negociantes residentes na cidade, solicitando que o "edifício do Largo da Liberdade destinado ao Mercadinho seja empregado ao fim a que foi feito". Os signatários alegavam razões de conveniência e ordem pública e concluíam que não havia motivo para não serem atendidos. Afinal, o prédio havia sido construído para abrigar vendedores de hortaliças, verduras e carne verde, mas que teve de enfrentar a tão criticada quanto combatida concorrência dos tanguás, que desviavam os consumidores das "respeitáveis" casas comerciais dos signatários da representação.

Ficava claro o quanto os mercados ajudavam e fomentavam o florescente comércio campineiro, em uma relação muitas vezes contraditória com outros locais de compra e venda e com a própria organização espacial de Campinas e do cotidiano de seus moradores. A Comissão de Justiça da Câmara, depois de tantas tentativas para dar vida ao Mercado de Hortaliças e de receber propostas variadas para utilização de seu prédio, deve ter julgado o pedido dos comerciantes no mínimo estranho, e por esse ou outro motivo simplesmente o indeferiu. ${ }^{29}$

Depois disso, seria de se esperar que o Mercadinho logo cumprisse seu malfadado destino e fechasse definitivamente suas portas, tão poucas vezes abertas. Mas não foi o que ocorreu. Aquele espaço, enfim, assumiu suas funções

\footnotetext{
${ }^{28}$ ACMC, 04/03/1889; ACMC, 02/09/1889.

${ }^{29}$ ACMC, 09/12/1889; ACMC, 07/01/1890.
} 
de abastecimento da população. As coações econômicas (a licença cara) e as batidas policiais devassando os tanguás, surtiram seus efeitos.

Por outro lado, a abolição da escravidão colocou fim nos temores quanto a possíveis revoltas tramadas no interior dos tanguás. Os "frejes", que parecem ter sido a versão republicana dos tanguás, continuaram como pontos de encontro, abastecimento e sociabilidade das classes populares que, daquele momento em diante, mais que preocuparem as autoridades quanto ao aspecto da moralidade, passaram a preocupar principalmente quanto à vadiagem de seus freqüentadores, muitos deles, ex-escravos. A nova ideologia do trabalho, gestada ainda no Império, assumida e levada a sério pela República, manteria aqueles espaços da cidade bem como botequins e vendas estritamente vigiados pela polícia, cada vez mais investida da missão do controle social das classes populares (perigosas?) nas cidades brasileiras. ${ }^{30}$

\section{Referências Bibliográficas}

CHALHOUB, Sidney (1986). Trabalho, lar e botequim: o cotidiano dos trabalhadores no Rio de Janeiro da Belle Époque. São Paulo: Brasiliense.

DAVATZ, Thomas (1980). Memórias de um colono no Brasil. Belo Horizonte/São Paulo: Itatiaia/EDUSP.

DIAS, Maria Odila Leite da Silva (1984). Quotidiano e poder em São Paulo no século XIX. São Paulo: Brasiliense.

FIGUEIREDO, Luciano (1993). O avesso da memória. Cotidiano e trabalho da mulher em Minas Gerais no século XVIII. Rio de Janeiro: José Olympio.

FREIRE, Laudelino (1957). Grande e Novíssimo Dicionário da Língua Portuguesa. $3^{\circ}$ ed. Rio de Janeiro: José Olympio.

LAPA, José Roberto do Amaral (1996). A cidade. Os cantos e os antros São Paulo: EDUSP.

MARTINS, Valter (2001). História de compra \& venda. Mercados e abastecimento urbano em Campinas,1859-1908. Tese de Doutorado FFLCH/USP.

\footnotetext{
30 Sobre a nova ideologia do trabalho, combate à vadiagem e controle social no início do século XX veja: (CHALHOUB, 1986).
} 
SOARES, Carlos Eugênio Líbano (1998). Zungú: rumor de muitas vozes. Rio de Janeiro: Arquivo Público do Estado do Rio de Janeiro.

Texto recebido em 27/09/2007. 